\title{
STRENGTHENING INCLUSION OF LEARNERS WITH ATTENTION DIFFICULTIES THROUGH INTERVENTIONS WITH DIGITAL TECHNOLOGY IN PROCESSES OF PRODUCTION
}

\author{
Elsebeth Korsgaard Sorensen[elsebeth@learning.aau.dk], HanneVoldborg Andersen \\ [voldborg@learning.aau.dk], Aalborg University [bttp:/ / learning.aau.dk], Kroghstraede 3, 4.149, DK-9220 \\ Aalborg Oest, Denmark
}

\begin{abstract}
This paper investigates the potential of digital technologies for strengthening the participation and inclusion of learners with developmental and attention deficits (focus learners) into the mainstream classroom. The paper describes the authors' approach to the challenge of researching the extent, to which digital technologies may support the learning process of focus learners - in particular in those aspects of the learning process that deal with the construction of learning products and the communication and dissemination of knowledge to peers, teachers or others. On the basis of the actual analysis and a succeeding discussion, the paper concludes that in order to create ownership, pedagogic strategies and interventions with digital technologies (whether viewed from the perspective of teaching or the perspective of learning) should incorporate opportunities for developing digital multimodal reifications. These, in turn, then stimulate learner reflection and awareness. Finally, the authors of the paper emphasize importance of opportunities for reflection, tools and structures for construction and dissemination of learners' knowledge (to demonstrate "I am able to" and "I know").
\end{abstract}

\section{Abstract in Danish}

Denne artikel undersøger potentialet af digital teknologi for at styrke deltagelse og inklusion af elever med opmærksomhedsproblemer (fokus elever) i Folkeskolens normalklasser. Artiklen beskriver forfatternes tilgang til den udfordring det er at udforske graden af den support, som digitale teknologier tilbyder fokuselevers læreproces - især mht. de aspekter af læreprocessen som drejer sig om konstruktion af læringsprodukter og kommunikation/videndeling hos lærere og lærere-elever imellem. På basis af analysen og den efterfølgende diskussion, konkluderer artiklen at det $\mathrm{i}$ forhold til at understøtte ownership, er nødvendigt at pædagogiske strategier og intervensioner med digital teknologier i relation til denne målgruppe (uanset om perspektivet er undervisning eller læring) bør indeholde muligheder for at udvikle og producere digitale reifikationer, da disse synes at stimulere refleksion og styrke awareness generelt hos fokuseleverne. Endelig understreger forfatterne til artiklen vigtigheden af at etablere muligheder for refleksion, værktøjer og strukturer til konstruktion og udbredelse af fokuselevernes selverkendelse (at demonstrere "jeg kan dette" og "jeg ved dette”).

\section{Introduction}

It is beyond any doubt that the last decade of digital technologies and social networks has produced a changed educational environment (Conole, 2013). New possibilities for digital educational approaches, tasks and methods have come into focus. In general, this situation has offered new possibilities for inventing novel pedagogies resting on the affordances and utilization of digital technologies. It has enabled new educational designs, which - to a higher extent than earlier - rest on pedagogical bottom-up approaches (e.g. Sorensen, 2014), which offer learners an 


\title{
Strengthening Inclusion of Learners With Attention Difficulties Through Interventions With Digital \\ Technology In Processes of Production \\ Elsebeth Korsgaard Sorensen, Hanne Voldborg Andersen
}

alternative way of becoming involved in the educational process as true agents. Simultaneously, the societal/governmental demand has increased dramatically in terms of schools to be able to include children with special educational needs (SEN) in the mainstream classroom.

The present paper uses the term focus learners to denote kids and youngster with developmental and attention deficits in the "Syndrome Mix" (Kutcher et al., 2014) of Attention Deficit Hyperactivity Disorder (ADHD), Learning Disabilities (LD), Autism Spectrum Disorders (ASD), Tourette, Anxiety and more. It addresses the challenge of including these focus learners, which at various levels struggle with problems according to one or more of these generally acknowledged areas (Barkley, 2006; Barkley, 2013; Faraone et al., 2005): memory, attention, persistence, hyperactivity, impulsivity, behaviour, emotions, pro-social behaviour, problems with friends, comprehension and conception, language and communication.

The characteristics and symptoms of the group seem sensitive to the situated demands and the level of cognitive complexity of a task (Barkley, 2006). Their attention can rapidly fluctuate, and they are driven mainly by motivation arising from their hyperactivity and impulsivity. It is widely recognised, that children with developmental and attention deficits call for both support, praise, acknowledgement and appreciation combined with clarity, aid and strategies to master complications in their tasks at school (ibid.). Poor school performance, social problems with peers and authorities (e.g. parents and teachers) combined with lacking self-confidence or selfesteem draw the picture of many youngsters with ADHD, where $65 \%$ of them are still affected by their ADHD in the adulthood (Faraone et al., 2005).

The number of learners in primary and secondary schools with challenges as described above has increased tremendously over the last decades (Due et al., 2014). Both teachers and schools are desperately looking for new methods and approaches to help the inclusion of focus learners in the mainstream school system (Danmarks Evalueringsinstitut, 2011). The contribution of this paper is to investigate whether the potential of digital technologies may contribute to support the challenge of inclusion of youngsters with developmental and attention deficits in general schools - specific according to their ability to join and participate in learning processes that deal with construction of learning products and the communication of knowledge to peers, teacher or others.

\section{Analytical Optic}

\begin{abstract}
"Experience is, for me, the highest authority. The touchstone of validity is my own experience. No other person's ideas, and none of my own ideas, are as authoritative as my experience. It is to experience that I must return again and again, to discover a closer approximation to truth as it is in the process of becoming in me." (Rogers, 1961; pp.23-24)
\end{abstract}

From this viewpoint it becomes quite clear that - as claimed by both Rogers (1961) and later confirmed by Wenger (1998) - it is not possible to teach another person "directly". Rather, it is possible only to humbly facilitate his learning (Smith, 2004). But how, then, more closely, may the affordances of digital tools that facilitate genuine inclusive learning be assessed and understood? Dalsgaard and Sorensen (2008) offer a typology for digital tools that group these according to the indisputable affordances they offer in relation to two main types of functionality of learning: (a) Participation in processes of communication (dialoguing and stimulating the creation of communicative networks and awareness); (b) Participation in processes of production (using digital technologies to create and share digital products). Andersen and Sorensen (2015) see a great potential in these types of technologies, also for focus learners. 
Being utilized in the hands of teachers as tools for helping the inclusion in mainstream classrooms of youngsters with developmental deficits and difficulties in focusing attention (ibid.; Sorensen, Andersen, \& Grum, 2013) creates great expectations with respect to empowering learners and helping the process of inclusion. Empowerment may be defined as the ability and power to control one's own life in a manner that makes space for understanding, influence, and meaningfulness in a way that promotes insight, transparency and ability to act as an active citizen. Empowerment is both a process and a goal in itself (Hoskins et al., 2006; Meyer et al., 2007; Sorensen, 2014). But which qualities of learning, does a process of genuine inclusive learning carry along? In Rogers' concept "experiential learning", the main focus is on personal change and growthand on the experience of the learner of being included. While generally acknowledging the significance of collaborative learning methods, Sorensen and Ò Murchú (2005) - inspired by Rogers (1969) and Colaizzi (1978) - presents an attractive existential understanding of the concept genuine inclusive learning. The following principles for when authentic inclusive learning can be said to take place, may be distilled:

1. when a learner participates and controls a significant, relevant process that is true to $\operatorname{him} /$ her;

2. when a learner participates and external threats are low; and

3. when reflection and meta learning (i.e. learning-to-learn) are the primary methods of assessing progress or success.

Using the above generated optic, this paper wishes to explore the ways in which digital modes of expression and opportunities for participation in processes of production of visible reifications (i.e. structures for constructing, disseminating, reifying) may assist the inclusion of youngsters with developmental difficulties and difficulties in focusing attention: How may focus learners enhance their possibilities for developing a conscious and reflective understanding of their own capabilities and competencies?

\section{Research Design}

This piece of research is one of the outcomes from a wider research design, Ididakt, by Andersen and Sorensen (2015), Andersen (2015) and Sorensen, Andersen, and Grum (2013). A key element in the research design is that the research process integrates the teachers and goes hand in hand with their work and interventions into the field of study, and become a learning process for them in how to work with SEN learners and integrating ICT in the classroom and that the research process takes place in the real life context of the mainstream classroom (Andersen \& Sorensen, 2015).

Therefore, Ididakt is an iterative and explorative research project, where data is collected in a real school context. It is a case study in the frame of Educational Design Research (EDR) (McKenney \& Reeves, 2012) using a hermeneutical phenomenological interpretation of data. EDR is a "genre of research, in which the iterative development of solutions to practical and complex educational problems also provides the context for empirical investigations, which yields theoretical understanding that can inform the work of others" (ibid.; p.7).

Ididakt was running 2013-2015 in two loops, where 11 general schools participated in the development of new including ICT-based pedagogical approaches. The researchers operated as facilitators and professional dialogue partners in transformation processes in the schools involved. 46 teachers contributed with their experiences from using including ICT-based interventions, and the data are collected through their descriptions and reflections in blog entries, interviews, statements at seminars and in surveys. Concurrently, 56 focus learners were identified 


\section{Strengthening Inclusion of Learners With Attention Difficulties Through Interventions With Digital \\ Technology In Processes of Production \\ Elsebeth Korsgaard Sorensen, Hanne Voldborg Andersen}

in 26 participating classes (age 6-16), where more than 500 learners in total have used different kinds of technologies in their learning processes. The 56 focus learners' challenges at school are exposed before and after the intervention periods.

The data are analysed in several processes, where the first naïve readings uncovered themes for further iterations. Early findings generated an intervention model mirroring five types of ICTbased including interventions (Andersen \& Sorensen, 2015):

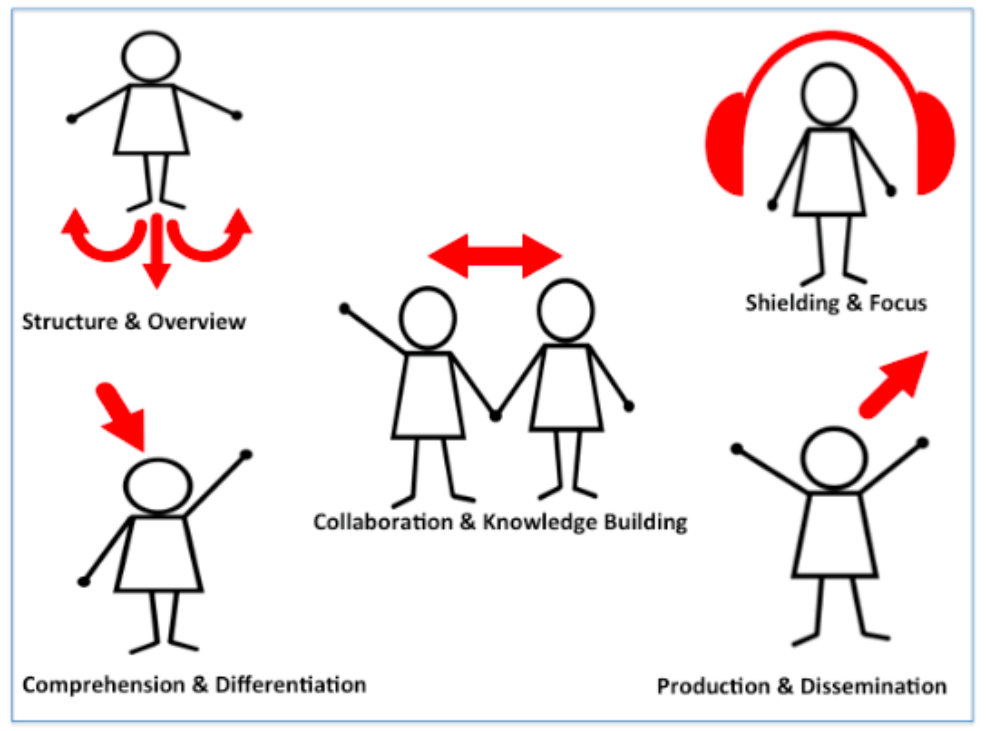

Figure 1. Iterations of a five-type-model of including ICT-based interventions

While these five intervention types are presented and discussed in separate research papers (Structuring \& Overviewing (Andersen \& Sorensen, 2016a; Sorensen \& Andersen, 2016b), Shielding \& Focussing (Andersen, 2015), Differentiation \& Comprehension (Andersen \& Sorensen, 2016c), Production \& Dissemination (Sorensen \& Andersen, 2016c) and Dialoguing \& Collaborating (Sorensen \& Andersen, 2016b)), this paper will be dealing with the extent to which participation and contribution of focus learners may be enhanced through the use of the ICT-based intervention for Production \& Dissemination. The following analysis is therefore conducted to identify how the technologies have been utilized to facilitate production and dissemination in the classroom settings, and how the focus learners reacted, when using them.

\section{Analysis and Findings}

Our analytical optic distilled 3 principles for when authentic inclusive learning can be said to take place:

1. when a learner participates and controls a significant, relevant process that is true to $\operatorname{him} /$ her;

2. when a learner participates and external threats are low; and

3. when reflection and meta learning (i.e. learning-to-learn) are the primary methods of assessing progress or success.

It seems that several learners experience structural support for the management of learners' processes. Interventions with structuring tools/interventions seem likely to scaffold and through that - facilitate process, and thus, enhance participation of learners. While providing structures/templates that give more overview and guidance of the task at hand, learners are more 
likely to feel inclined to participate, if their level of frustration is comfortable. Structures/templates scaffold enhanced understanding and stimulate a feeling of safe ground to act.

Learner participation appears to be a central element in the process of using technology. It suggests 3 functions of technology and digital templates/structures in the scaffolding of the learning process: as scaffolding the individual learning PROCESS that evolves and progresses, and scaffolds PRODUCT creation, while finally ASSISTING the cognitive and meta cognitive processes involved in reading and writing (facilitating comprehension and communication).

Summing up, Table 1 mirrors the overall implementation of interventions in contexts of Production \& Dissemination (Andersen \& Sorensen, 2015; Figure 1), as well as the specific impact from the analysis.

Table 1: Technologies used in context and the impact of the ICT-based interventions

\begin{tabular}{|c|c|c|c|}
\hline $\begin{array}{l}\text { Overall types } \\
\text { of } \\
\text { interventions } \\
\text { in use context }\end{array}$ & $\begin{array}{l}\text { Digital } \\
\text { structures/templates } \\
\text { scaffolding learning } \\
\text { PROCESS (e.g. templates, } \\
\text { document sharing, } \\
\text { overviewing or learning } \\
\text { management tools) }\end{array}$ & $\begin{array}{l}\text { Digital } \\
\text { structures/templates } \\
\text { scaffolding reification of } \\
\text { PRODUCT (e.g. } \\
\text { presentation tools, multi- } \\
\text { modal production tools for } \\
\text { creation of text, image and } \\
\text { video) }\end{array}$ & $\begin{array}{l}\text { Digital } \\
\text { structures/templates } \\
\text { ASSISTING } \\
\text { comprehension and } \\
\text { communication (e.g. Text- } \\
\text { to-Speech or Speech-to- } \\
\text { Text technologies, word } \\
\text { prediction or } \\
\text { communication tools) }\end{array}$ \\
\hline $\begin{array}{l}\text { Technologies } \\
\text { used }\end{array}$ & $\begin{array}{l}\text { Templates in Word, } \\
\text { Powerpoint, Google } \\
\text { Docs, Google Slides or } \\
\text { BookCreator } \\
\text { Document sharing in } \\
\text { Google Drive, Office 365, } \\
\text { Showbie, Dropbox etc. } \\
\text { Overviewing in } \\
\text { Mindmeister } \\
\text { Learning Management in } \\
\text { Google Classroom, } \\
\text { Meebook, Google Sites }\end{array}$ & $\begin{array}{l}\text { Productions tools as } \\
\text { PowerPoint, Word, Google } \\
\text { Docs, Google Slides, } \\
\text { iMovie, BookCreator, } \\
\text { WriteReader or Skoletube } \\
\text { Tools (Danish collection of } \\
\text { free online ressources as } \\
\text { GoAnimate, PowToon, } \\
\text { TikiToki, Pixton etc.) }\end{array}$ & $\begin{array}{l}\text { Text-to-Speech and Word } \\
\text { Prediction technologies as } \\
\text { CDord, AppWriter og } \\
\text { IntoWords } \\
\text { Speech-to-Text } \\
\text { technologies as Dragon } \\
\text { Dictation, iVoiceAssistant } \\
\text { or Siri } \\
\text { Communication tools as } \\
\text { Skype, Google Hangouts } \\
\text { or Chat }\end{array}$ \\
\hline $\begin{array}{l}\text { Impact on } \\
\text { participation }\end{array}$ & $\begin{array}{l}\text { Creates "safe ground" } \\
\text { Supports motivation } \\
\text { Supports multimodal } \\
\text { expression and } \\
\text { communication } \\
\text { Helps contribution } \\
\text { Helps collaboration } \\
\text { Reduces risks } \\
\text { Reduces anxiety }\end{array}$ & $\begin{array}{l}\text { Appears open/inviting } \\
\text { Provides structure and } \\
\text { guidance } \\
\text { Supports multimodal } \\
\text { expression and } \\
\text { communication } \\
\text { Reduces learner insecurity } \\
\text { Supports sharing and } \\
\text { disseminating }\end{array}$ & $\begin{array}{l}\text { Provides self-control } \\
\text { Supports learners } \\
\text { Saves cognitive energy } \\
\text { Reduces risk for failure } \\
\text { Increases success }\end{array}$ \\
\hline
\end{tabular}

The more detailed analysis of each of the three groups of interventions is organized according to the parameters of the learning quality they involve and support. 


\section{Strengthening Inclusion of Learners With Attention Difficulties Through Interventions With Digital \\ Technology In Processes of Production \\ Elsebeth Korsgaard Sorensen, Hanne Voldborg Andersen}

\section{Digital templates/structures for learning PROCESS}

Our investigations in Ididakt mirror focus learners, who are not able to create learning products and disseminate knowledge at the same level as their peers. It is widely recognised, that such groups of children as denoted here as focus learners, call for not only support, praise, acknowledgement and appreciation, but also clarity, aid and strategies to master complications in their tasks at school. It is difficult for them to plan written assignments, to create structure for that, which they want to convey, and to produce the content. They lose the thread, when they need to focus on more work processes at the same time, e.g. to both create a story and spell correctly.

We have investigated if it may help focus learners creating productions, when they use digital tools, which offer them plans and strategies for the work, while at the same time increasing their reifications, reflections and possibilities of communication through use of multi-modal communications and assisting digital tools.

10 out of 11 schools have used writing templates to enhance focus learners' possibility for solving assignments, reify their knowledge and communicate this to teachers and peers. Writing templates can offer the focus learners a frame for the task at hand, so that it is split into smaller subtasks, possibly with little pieces of explanatory "bridges", check boxes etc. The writing templates are created by the teachers in software such as Powerpoint/Slides, Word/Docs, BookCreator, or they are bought in the form of apps, e.g. Write \& Learn. The teacher-produced templates can be made for specific topics/purposes, e.g. analysis of a novel - or be of a more general nature for a specific type of assignments, which the learners work with regularly, e.g. a novel, a report, etc.

The templates may be very simple, like e.g. a Google Doc with a table of contents suggestion for the focus learners, so they do not have to start from scratch, but have something to choose from. The templates may also be more detailed, like e.g. a BookCreator template with predefined assignments for literary work with a youth novel:

"We start with a description of the goal and assembles the pages, so the learner him-or herself can increase or decrease the level of scaffolding and guiding. In more places the written presentations are supplemented with sound and images accompanied with instructions and explanations" (teacher, school A).

They also work with double-scaffolding, where

"task solving are supported both generally by OneNote and concretely in PowerPoint (or generally in Google Websites and concretely in Google Slides): Analysis assignments in Danish literature become simplified and structured to offer the focus learner an overview, which he/she due to NLD has an extensive challenge to create. The rest of the learners in class are offered the same tool" (teacher, school K).

The teachers observe how the templates are able to create an increased focus on the topic at hand for focus learners. They can insert technical terms, which the class is focusing on, and put these to work in the reflections and reifications of the learner:

"The template provides focus learners with the courage to start with the task and makes them more motivated for task solving. The templates work well for all. Those with a surplus on the topic are able to simply transcend the frames. It does not impede anyone, rather it benefits them all" (teacher, School F). 


\section{Strengthening Inclusion of Learners With Attention Difficulties Through Interventions With Digital \\ Technology In Processes of Production \\ Elsebeth Korsgaard Sorensen, Hanne Voldborg Andersen}

The templates may cover different functions for the focus learners:

"For $M$ it is about gaining structure in relation to the content, for B it is about fear for the white paper. He needs a frame in order to get motivated to solve a written task" (ibid.)

The teachers describe how focus learners become more motivated, take more responsibility, demonstrate ownership and are participating in the whole task. They confirm that the templates are working well for all and provided them with a feeling of success:

\section{"After the project week he was able to present really well in front of the whole class" (ibid.)}

In Ididakt writing templates are used in a variety of tasks. Table 2 mirrors selected examples of use of writing templates and their values for focus learners.

Table 2: Examples of use of writing templates - and their significance for focus learners

\section{Open weekly writing assignment (Subject: Danish Literature)}

The teacher has made a comparison between paper template and Google Slides: "There is no doubt that A has achieved much more in Google Slides, than what he achieved in the paper version. Both $\mathrm{M}$ and $\mathrm{A}$ seem supported by the template. It helps them to assign structure to a task. It provides them with a fixed frame to meet an otherwise open and complex task. What does the writing template provide and what does the adult support provide? However, I have no doubt that the writing template constitutes a certain part of the support for the learner to produce something, as we have earlier seen these learners in smaller groups without getting anything produced" (teacher, School I).

\section{Book Review, $4^{\text {th }}$ grade (Subject: Danish Literature)}

The teacher starts to use writing templates and observes a focus learner while he/she is working with the assignment in class: "At this point I noticed that B was able to, independently, start working with a task and solve it in the lesson. I noticed that he worked systematically while using the template. It is the first time ever that I have observed that B independently has solved a written assignment within the lesson" (teacher, School F).

\section{A fairy tale template, $4^{\text {th }}$ grade (Subject: Danish Literature)}

The same teacher continues the intervention, but observes another focus learner: " $\mathrm{M}$ has succeeded in writing a fairy tale in the template. He says he had a good process. He was nervous that it would end up being too long, because 'there is a lot inside my head, which needs to be implemented in the task, many details'. $M$ has had oral feedback during the process. He did not succeed in finishing the narrative, before he started writing.... a writing template would have been a good support to obtain structure and independence in M's process" (teacher, School F).

\section{Project work, ESO, $10^{\text {th }}$ grade (Subject: Cross Curriculum Project)}

A rather challenged focus learner was not able to structure larger assignments and did not have any experience with finishing assignments. The teacher created a template and a structure for him in OneNote. In the class shared Notebook the teacher inserts a tab, which all the learners may choose to use. The tab contains 7 pages: (a) Content of task, (b) a scheme for keeping track of 
progress, (c) a week plan, (d) problem statement, (e) structure for report, (f) inspiration for content, (g) folder about the ESO task. "This structure provided $\mathrm{N}$ with a lot of help in relation to structure and overview, and he ended up producing a wonderful task and product within the given time frame, and he had a very good week. That he was not able to do earlier" (teacher, School K).

\section{Monthly assignment, ${ }^{\text {th }}$ grade (Subject: Danish Literature)}

The learners are supposed to record a poem and to find images and music that fits with it. "P has difficulties in formulating something in writing, so I created a template for him. He also produced a poem, but it was difficult for him to choose music on the internet - there were too many choices" (teacher, School B).

\section{Text analysis, $8^{\text {th }}$ grade (Subject: Danish Literature)}

"The learners solve their task in a word template. No-one has asked, where they could find it. No-one has been doubting how they should start. The template explains the task. It is located in Intra. The structure is clear and familiar for the learners" (Obs., School J).

\section{Project work, $8^{\text {th }}$ grade (Subject: History)}

"K. works on a history assignment. He works on a concept template. The teacher helps putting words in the template. E.g. the word 'crisis'. He reads in the history book and on the internet about farming. He writes explanations in the template and checks words in Ordbogen.com" (Obs., School J).

\section{Novel writing, $6^{\text {th }}$ grade (Subject: Danish Literature)}

The teacher creates a template for a focus learner, who manages quite well genre, content, etc. "But she is not able to generate ideas for that, which she is supposed to insert (main character, conflict, elements). Perhaps she needs a more guiding context - also when it comes to content so there will be more alternatives to choose from. She gets stuck in creating ideas herself' (teacher, School G).

\section{Summary of news, $4^{\text {th }}$ grade (Subject: Danish Literature)}

"F watches UltraNews for kids [television program] on iPad. It takes 8. Minutes. After that she repeats the News items, she is able to remember, in the app 'Write and Read'. F easily manages navigation and orientation via recognizable icons, headlines and text boxes. Easy to handle. F's news book are created as follows: (a) inserts relevant images (support for memory), (b) writes short text piece for each of the news items (writing ability), (c) records the text (expanding, more knowledge), (d) goes through text with teacher - change from child spelling to adult spelling in independent textbox below F's text. 'Write and Read' is primarily developed for primary school, but for learners with massive learning disabilities, like $\mathrm{F}$ in $4^{\text {th }}$ grade, the app offers a super possibility for producing something independent, which in addition is really relevant. This activity with seeing and writing lasts all together one lesson, and F happily leaves the lesson with a feeling 
of having created something" (teacher, School D).

The examples from Table 2 show, how digital writing templates appear to be a strong tool in terms of supporting attention and concentration, and increasing productivity and finalizing tasks. The templates reduce the cognitive complexity of the tasks and offer focus learners the overview and the strategy, which they have difficulties establishing. They are offered the possibility of performing at the same level as their peers, to experience success, self-guiding, and to receive recognition for their work, which - in the long run - is likely to increase their feeling of security and self-esteem.

\section{Digital structures/templates for PRODUCT creation}

It is important for learners to be able to reify learning items (e.g. create and disseminate) and mirror learning processes. As for digital tools for reifying and for facilitating PRODUCT creation, teachers report that several learners find structural support as well as support for more "rich" expression through multimodal expression and visual communication. Templates seem to provide general support for various tasks. Teachers report that they help learners in general, as well as focus learners.

When focus learners solve their assignments using digital tools, they also are offered the possibility for communicating in more modalities than text. In text software (e.g. Word and Docs), presentation software (e.g. Powerpoint and Slides) and multimodal communication software (e.g. Mindmeister, Prezi, iMovie or BookCreator) the learners are able to create products, where they communicate using text, photos, graphics, sound, video in multimodal narratives. Table 3 shows an example of a multimodal production process.

Table 3: An example of a multimodal production process

\section{Production, $4^{\text {th }}$ grade (in Ididakt)}

"The learners create narratives of Soria Moria Slot in iMovie and upload them to 'Skoletube'. Each learner produces in groups one part of the narrative, and they create the illustrations themselves as analogue drawings, which they then photograph and use digitally. They learn how they via the process of zooming in and out, etc. may have several illustrations in the same drawing. They produce keywords for their stories. They are not allowed 'to read', when they make speak-over, but to use their own words. They create keywords and practice" (obs., School F).

The value of focus learners communicating multimodally seems obvious. An actual before/after case is not easy to report, as many of the focus learners have never experienced a school or a life without these digital tools. When we meet them, they have several years of experience in using digital tools. Therefore, in this respect we must use the statements of the teachers and the focus learners:

"R. manages much better, when he is allowed to work multimodally" (teacher, School B)

" $M$ was very engaged when working with the math videos. He is able to record and explain mathematic calculations about speed. Creates a really good film" (teacher, School K) 


\section{Strengthening Inclusion of Learners With Attention Difficulties Through Interventions With Digital \\ Technology In Processes of Production \\ Elsebeth Korsgaard Sorensen, Hanne Voldborg Andersen}

"It is better than the hand. It is hard to write in handwriting mode, and it does not appear nicely. When we are to create something in iMovie, then most learners become bappy" (learner, School F)

"K may in alternative activities - physical, film, drama - all of a sudden provide a surprise. Otherwise, he is difficult to engage" (teacher, School K)

It is important that focus learners are familiar with the software, and the teachers should make a strategy for how generally the class should go about learning these. At one school we observed how learners throughout a school year, methodologically and structured, were taught to use tools such as e.g. Google Apps or CDord and were achieving fine results with all their focus learners. In other cases we observed a more random approach, where it was more incidental if the teacher and learners managed the technologies used. It becomes the responsibility of the focus learner, whether he/she is able to manage the technologies used at school, and in such cases the technologies are used to a smaller degree. It is also important that the learners are familiar with the format of the tasks. Focus learners, who do not have experience with creating sound recordings or videos, are hesitant to use these possibilities. The teachers should introduce the types of format to the whole class, so that all the learners have a repertoire of response formats/possibilities, they can choose between.

In general, there appears to be a good collaboration between focus learners, when they create digital products. They help each other and have different roles or exchange roles when they do different things. They can show each other possibilities, press un-do go back without having to start from scratch again. When the product is finished, they are no longer able to tell who produced what. The learners appear happy and content and take shared ownership to the product:

\section{"It is easier on the computer instead of cutting and pasting. The result becomes nicer, and it means a lot to me" (focus learner, School J)}

We often see how most focus learners take a different role, when they work digitally. They appear more participating and may, to a higher extent, contribute technically or content wise. But it is important that the teachers are open for expanding the response possibilities in format and focus on the content. When such principle is followed, it will become possible for more learners to achieve successes, as in the case of a very dyslexic boy (M) with ADHD. M's self chosen task is about a future education/job:

"W as very much stuck in the beginning of the week, when he thought he were to write a long essay. Spoke with him about it and told him that the essay did not have to be a long one, and that he had the choice of making a practical task and a series of images of the process instead. He presented for the class and scored a 10" (teacher School K)

Several teachers look upon structuring tools (e.g. BookCreator) as user friendly tools that are able to scaffold the creation of a product in a fast and easy manner:

"User-friendly tool, with a book as a quick result. The learner may easily navigate and orient himself via recognizable icons, headings and text boxes" (teacher statement, School d, $4^{\text {th }}$ grade)

Digital technologies offer possibilities for multimodal expressions/communication amongst learners. 


\section{Strengthening Inclusion of Learners With Attention Difficulties Through Interventions With Digital \\ Technology In Processes of Production \\ Elsebeth Korsgaard Sorensen, Hanne Voldborg Andersen}

"The tasks the learners are supposed to carry out vary between written, sound or image production. The learners can continuously choose which task they engage with/in and which form of expression they want to use" (teacher statement, $S$ chool $A, 7^{\text {th }}$ grade)

However, technologies (and other open educational resources), are not always perceived by teachers as simple pedagogical tools:

"A student by accident erases everything. It is difficult on iPads, on which there is no undobottom in apps" (teacher statement, School I, $2^{\text {nd }}$ grade)

But there is also the opposite experience:

" $\mathrm{R}$ is doing well, when he is allowed to work multi-modally. He has done well with a home assignment on family heritage" (teacher statement, School B, $6^{\text {th }}$ grade)

Teachers may help learners to produce reifications of their learning processes and their work. This may be done in a variety of ways.

"The teacher may put in relevant concepts and ask the class to reflect and reify" (teacher statement, School F, $4^{\text {th }}$ grade)

"Learners work in PowerPoint or Prezi. They are to make an assignment about Punk.

They are working independently, or in pairs" (Observations, $10^{\text {th }}$ grade)

A focus learner use a tablet and a speech-to-text software.

"It is because it helps a lot" (teacher statement, School B, $\sigma^{\text {th }}$ grade)

It enables learners to produce written texts verbally.

An example of a way of working multi-modally:

"Learners make re-tellings of Soria Moria castle in iMovie and upload to Skoletube. They produce together in groups part of the story, and they produce the illustrations. In this way they learn - zooming in and out - how they may use several illustrations in the same drawing. Learners produce keywords for their stories. They are not reading, when they produce speakover. They must repeat in their own words. They produce keywords - and practice" (Observations, $4^{\text {th }}$ grade)

In general, it seems that the book template spawns motivation, ownership, and learner responsibility.

In sum, digital structures appear to be fruitful tools supporting participation - and, thus, promoting inclusion - as they seem to structure the learning process and therefore invite, enable and empower the learner to participate.

\section{Digital structures/templates ASSISTING communication (facilitating reading and writing)}

Teachers observe that a large proportion of focus learners seem inhibited by difficulties in reading and writing (facilitating comprehension and communication). This affects their processes of acquisition and dissemination of knowledge. In terms of digital templates/tools and digital 


\section{Strengthening Inclusion of Learners With Attention Difficulties Through Interventions With Digital \\ Technology In Processes of Production \\ Elsebeth Korsgaard Sorensen, Hanne Voldborg Andersen}

interventions for assisting focus learners' comprehension and communication, teachers report of a high level of unambiguous success.

Digital technologies for production and communication provide focus learners with a possibility for using compensating tools with Text-to-Speech, WritingSupport and Speech-to-Text.

Tools such as CDord, IntoWords and AppWriter are used for reading aloud texts and for writing support in relation to focus learners' production of text. These are widely used tools in mainstream schools. But not only does it vary, how methodically the tools are utilized, there are also big differences in the teachers' and learners' level of experience and competence in using the tools. Some schools work very structured teaching all learners, making the tools common resources to be used when needed. They become part of the learners' repertoire, and we/the teachers observe focus learners, who work independently, express joy and experience successes through being able to, independently, manage the tasks:

"In the $2^{\text {nd }}$ module A were to solve 4 grammatip.com tasks. 'That I cannot manage on my
own', was his first reaction. I had the possibility of sitting down and show him, how he should
approach working independently with the task. [and use CDord]. A were allowed to sit in
the corridor (is experienced as a privilege), and he reluctantly started working. I told him,
that I was certain, he could manage the task. ok. Shortly after he fetched me. It didn't go well
- it went super well', A announced. He carried out the remaining tasks in the same way:
One task, then fetched me, then received praise. When he was finished with all the tasks, his
eyes radiated an enormous amount of pride" (teacher, School D)

Tools for text production, such as e.g. Voice Assistant, Dragon Dictation and Dictus, where the learner records the text, which the software writes, was tested in Ididakt, but the technologies are new and constitute many challenges of implementation. There are very positive experiences with a learner, who works very structured using speech-to-text:

"N has started using his Nexus. I had imagined that he would use it to record entire pieces of text. So far, instead, he has been using it as writing support for single words. The last week, he has produced mere in writing in his Danish lessons that ever before" (teacher, School B)

We are convinced that the increased access to speech-to-text technologies (e.g. Siri) following the technological developments implies a large potential for focus learners. It becomes possible for those who easily loose attention, loose the thread, lose concentration, and those who fight with difficulties related to change between two parallel work processes (e.g. spelling and composing) to put words on experiences or to communicate experiences to others, while using speech-to-text tools.

\section{Discussion}

Our analysis shows that focus learners gain a lot of help, support and opportunity from teachers' interventions with digital tools. Organized in different categories, it demonstrates how digital technologies and interventions to a certain extent seem to provide focus learners with "handy" methods and tools for managing and participating in learning processes. It is vital in the process of becoming aware to employ the digital tools to facilitate reifications (visualization, organisations, etc.) in such a way that the focus learners get to see/realize what they themselves KNOW. Our investigation has employed digital tools and interventions in learning situations with the aim of supporting, in particular (a) the facilitation of PROCESS, (b) the creation of PRODUCTS and, finally, (c) the ASSISTANCE with aspects of production and dissemination. 


\section{Strengthening Inclusion of Learners With Attention Difficulties Through Interventions With Digital \\ Technology In Processes of Production \\ Elsebeth Korsgaard Sorensen, Hanne Voldborg Andersen}

It becomes clear that good quality interventions with digital technology invite and support participation and dialogue - also in the planning of the learning process of the individual focus learner. Good quality interventions incorporate tools and structures for construction and dissemination of learners' knowledge (to demonstrate "I am able to" and "I know"), diverse, multimodal and assistive digital modes for communicating, collaborating and contributing - and opportunities for reflection. However, it also becomes clear to us that teachers not always perceive technologies as simple pedagogic tools. In between we have met with disillusioned statements from the teachers concerning their use (or non-use) of digital tools:

"I have downloaded the software, but it does not work, neither on my own iPad, nor on the iPad of the school" or "I cannot come back again after an attempt to mail my text out of iV oice, and I cannot find an overview of the texts that I have recorded" (teacher, School C)

We made an attempt to convince teachers to start using Speech-to-Text technologies for learners and, before the learners go to independent boarding school after the $9^{\text {th }}$ grade. But teachers comment that there is not enough time to teach learners how to use these technologies. The feeling of powerlessness among teachers seems still to be a very frequent and general problem (Andersen \& Sorensen, 2016a). But there is also the opposite experience. Even though technologies seem helpful for many focus learners - "R. is doing well, when he is allowed to work multi-modally, and he has done well with a home assignment on family heritage" (teacher, School B) - technologies also cause unintended disruptions - "A student by accident erases everything, it is difficult on iPads, on which there is no undo-bottom in apps" (teacher, School I, $2^{\text {nd }}$ grade). It appears very important that the teachers master the technology in a way that they are able to both help the learner with such unintended actions, and that they are able to exploit the affordances of the technologies in their pedagogical practice.

To be included is, in itself, a life value for the unique individual/learner. To feel included, a learner must feel safe and secure in the learning endeavour. The reversibility of learning actions in a digital learning environment makes it much safer for focus learners to navigate in a "safe" environment. Reducing risks in the processes of creating learning products and reifying processes of learning is important in order to ensure that focus learners will have a voice in the choir of change and the democratic advancement of society.

\section{Conclusion}

This paper has demonstrated how various types of ICT-based interventions may be considered as tools for inclusion of learners with developmental and attention deficits in the Syndrome Mix of Attention Deficit Hyperactivity Disorder (ADHD), Learning Disabilities (LD), Autism Spectrum Disorders (ASD), Tourette, Anxiety and more (focus learners). The analysis has shown that learning interventions with digital technologies make focus learners thrive with a more fullregistered - digital and multimodal - way of expressing themselves while it offers them a wider repertoire of modalities in their academic tasks. Images can support lacking memory, and videos can expand written assignments and compensate for writing disabilities. While it invites and enables them to act in a new way, it also empowers them to take collaborative and multimodal communicative initiatives and, thus, express themselves more and better.

Using digital technologies enables learners to observe, inspect and reflect upon their own learning (their level of knowledge and process of learning), and to disseminate, demonstrate and make visible - through reifications - their own learning. The ICT-based interventions seem to act as a vehicle for enabling inclusion of focus learners through making visible what focus learners are actually able to do and what they know. This transparency can impact, positively, both the self- 


\section{Strengthening Inclusion of Learners With Attention Difficulties Through Interventions With Digital \\ Technology In Processes of Production \\ Elsebeth Korsgaard Sorensen, Hanne Voldborg Andersen}

esteem of focus learners ("see what I - as a learner - can do") or provide teachers with precious insight for evaluating the special educational support ("what else must we - as teachers - do").

The interventions, smoothness and reversibility of digital actions cause focus learners to feel safe and secure, and stimulate their inclination and courage to participate and interact, to become interested and authentically involved with tasks, assignments and peers. They simply become inclined to share, communicate and interact around learning endeavours, and to feel ownership to their own learning processes.

To reduce risks, any fruitful pedagogical approach should employ digital technologies and interventions in ways that empower learners and promote a learner experience of inclusion, and a feeling of being recognized as a valuable participating and contributing member of a group of peers sharing an inescapable context of mutual collaboration, dialogue and collaborative knowledge building (CKB) (Sorensen \& Andersen, 2016a; 2016b).

Finally, the authors of this paper emphasize the importance of providing focus learners' with tools and structures for construction and dissemination of their knowledge. Moreover, focus learners need supportive tools for comprehension of utterances and opportunities for reflection on what they know and are able to do. Our overall conclusion is that including pedagogic strategies and interventions with digital technologies to a wide extent appear valuable for the cultivation of inclusion of learners with developmental and attention deficits in mainstream schools.

\section{References}

1. Andersen, H. V. (2015). Supporting inclusion of learners with attention deficit-hyperactivity disorder in sound-field-amplification-systems. Proceedings of the $1^{\text {st }}$ D4Learning International Conference Innovations in Digital Learning for Inclusion.

2. Andersen, H. V., \& Sorensen, E. K. (2015). Technology as a vehicle for inclusion of learners with attention deficits in mainstream schools. Proceedings of European Distance and E-Learning Network (EDEN) Annual Conference, Barcelona, Expanding Learning Scenarios - Opening Out the Educational Landscape, 720-730.

3. Andersen, H. V., \& Sorensen, E. K. (2016a). Empowering Teachers and their Practices of Inclusion through Digital Dialogic Negotiation of Meaning in Learning Communities of Practice. Paper presented at the Edmedia, Vancouver.

4. Andersen, H. V., \& Sorensen, E. K. (2016b). Powerlessness or Omnipotence - the Impact of Structuring Technologies in Learning Processes for Children with Attention and Developmental Deficits. Proceedings of the $1^{\text {st }} \mathrm{E}$ AI International Conference on Design, Learning \& Innovation, May, 2.-3., 2016, Esbjerg.

5. Andersen, H. V., \& Sorensen, E. K. (2016c). Differentiated Technology-based Interventions for Enhancing Understanding, Flow and Self-efficacy by Learners with Developmental and Attention Deficits. Paper presented at the $9^{\text {th }}$ EDEN Research Workshop - EDENRW9, 4-6 October 2016, Oldenburg.

6. Barkley, R. A. (2006). Attention-Deficit Hyperactivity. A Handbook for Diagnosis and Treatment (3 ${ }^{\text {rd }}$ ed.). New York: Guilford Press.

7. Barkley, R. A. (2013). Taking charge of ADHD: the complete, authoritative guide for parents ( ${ }^{\text {rd }} \mathrm{ed}$.). New York: The Guilford Press.

8. Colaizzi, P. F. (1978). Learning and existence. In R. Valle \& M. King (Eds.), Existentialphenomenological alternatives for psychology (pp. 119-135). New York: Oxford University Press. 
9. Conole, G. (2013). Designing for Learning in an Open World. Heidelberg: Springer.

10. Dalsgaard, C., \& Sorensen, E. K. (2008). A typology for Web 2.0. (pp. 272-279). ECEL.

11. Due, P., Diderichsen, F., Meilstrup, C., Nordentoft, M., Obel, C., \& Sandbæk, A. (2014). Born og unges mentale belbred. Forekomst af psykiske symptomer og lidelser og mulige forebyggelsesindsatser. København: Vidensraad for Forebyggelse.

12. EVA. (2011). Indsatser for inklusion i folkeskolken. Retrieved March 18, 2013, from http://www.eva.dk/projekter/2011/undersogelse-af-skolens-indsatser-forinklusion/projektprodukter/inklusion

13. Faraone, S. V., Biederman, J., \& Mick, E. (2005). The age-dependent decline of attention deficit hyperactivity disorder: A meta-analysis of follow-up studies. Psychological Medicine, 36(2), 159-65.

14. Hoskins, B., Jesinghaus, J., Massimiliano, M., Munda, G, Nardo, M., Saisana, M., Van Nijlen, D., Vidoni, D., \& Villalba, E. (2006). Measuring Active Citizenship in Europe. CRELL Research Paper 4. EUR 22530 EN. Office for Official Publications of the European Communities. $2006 / 1 / 1$

15. Kutcher, M. L., Atwood, T., \& Wolff, R. R. (2014). Kids in the syndrome mix of ADHD, LD, Autism spectrum, Tourette's and mpre!: the one-stop guide for parents, teachers, and other professionals $\left(2^{\text {nd }}\right.$ ed.). London; Philadelphia: Jessica Kingsley Publishers.

16. McKenney, S., \& Reeves, T. C. (2012). Conducting Educational Design Research. New York: Routledge.

17. Meyer, B., Haas, C., Rørbech, H., \& Dahl Madsen, K. (2007). Demokratisk dannelse til aktivt interkulturelt medborgerskab. Sprogforum, 13(41), 14-20.

18. Rogers, C. R. (1961). On Becoming a Person. A therapist's view of psychotherapy. Boston: Houghton Mifflin (1967 - London: Constable).

19. Rogers, C. R. (1969). Freedom to Learn. Columbus, OH: Merrill.

20. Smith, M. K. (1997, 2004). 'Carl Rogers and informal education', the encyclopaedia of informal education. Retrieved May 29, 2012, from http://www.infed.org/thinkers/et-rogers.htm

21. Sorensen, E. K. (2014). Promoting Awareness and Ownership in Digital Processes of Teaching and Learning. Proceedings of the European Distance and E-Learning Network 2014 Research Workshop (RW8), Challenges for Research into Open \& Distance Learning: Doing Things Better - Doing Better Things, Oxford, October 27-28, 2014 ISBN 978-615-5511-00-4

22. Sorensen, E. K., \& Andersen, H. V. (2016a). Amplifying the process of inclusion through a genuine marriage between pedagogy and technology. Proceeding of the $25^{\text {th }}$ EDEN conference, June 14.-17., 2016, Budapest.

23. Sorensen, E. K., \& Andersen, H. V. (2016b). Learning Together Apart - the Impact on Participation when Using Dialogic Educational Technologies for Kids with Attention and Developmental Deficits. Proceeding of the $1^{\text {st }}$ EAI International Conference on Design, Learning \& Innovation, May, 2.-3., 2016, Esbjerg.

24. Sorensen, E. K; \& Andersen, H. V. (2016c). Using Digital Technologies to Strengthen Participation and Inclusion of Learners with Developmental and Attention Deficits. Proceeding at the $9^{\text {th }}$ EDEN Research Workshop - EDENRW9, 4-6 October 2016, Oldenburg. 
25. Sorensen, E. K., Andersen, H. V., \& Grum, H. (2013). Intercultural dialogic eLearning: A tool for fostering shared understanding and sustainable competence development in practices of inclusion. Victoria, BC: AACE - Association for the Advancement of Computing in Education.

26. Sorensen, E. K. \& Ó Murchú, D. (2004). Designing Online Learning Communities of Practice: A Democratic Perspective. Journal of Educational Multimedia (CJEM), 29(3).

27. Wenger, E. (1998). Communities of Practice. Learning, Meaning and Identity. Cambridge, UK: Cambridge University Press. 